\title{
ハーフブリッジ形イミタンス変換器
}

\author{
正 員 入江 寿一* 学生員 高山 長之*
}

\section{Half-Bridge Type Immittance Converter}

Hisaichi Irie*, Member, Nobuyuki Takayama*, Student Member

The immittance converter has the input impedance that is proportional to the admittance of the load connected across output terminals. Therefore, in this converter, the output current is proportional to the input voltage and the input current is proportional to the output voltage. Consequently, it converts a constant voltage source into a constant current source and a constant current source into a constant voltage source.

In this paper, we propose a new type immittance converter, named half-bridge type immittance converter, consists of a tapped transformer and a pair of L, C. The new immittance converter is developed from the hybrid type immittance converter, and has almost same characteristics of that.

キーワード：定電流源，イミタンス変換器，特性インピーダンス

Keywords: constant current source, immittance converter, characteristic impedance

\section{1. まえがき}

共振形イミタンス変換器は，リアクトル L とキャパシタ Cの集中定数受動素子のみで構成することができ，イミタ ンス変換特性によって，電圧源を電流源へ，電流源を電圧 源へと容易に変換することができる。共振形イミタンス変 換器は，その共振周波数でのみイミタンス変換特性を示す ので，インバータなどスイッチングモードの電力変換器の 高周波リンクに挿入して使用すると好都合である。

イミタンス変換器の電力变換特性に注目した最初の文献 は 1988 年に現れている(1)。イミタンス変換器を独立した 電力変換器としての取り扱ったのは, 1996 年の発表が最初 と思われる ${ }^{(2)}$ 。ここで 5 形式のイミタンス変換器の回路が 示されている。そのうちで, LCのブリッジで構成されるハ イブリッド形イミタンス変換器 ${ }^{(4)}$ は，特に高い効率と平坦 な周波数特性を持っているが，共振用の L, Cがそれぞれ 2 個ずつ必要であった。ここで提案するハーフブリッジ形 イミタンス変換器は, ハイブリッド形の片側とセンタタッ プトランスを用いて構成するものである。ハイブリッド形 と同様に，高い効率と平坦な周波数特性を持ちながら，共 振用の L ，C は最少の 1 個ずつで実現できる。

本文では，ハーフブリッジ形イミタンス変換器とハイブ リッド形イミタンス変換器のパラメータとの関連を示し, 両者は同じ特性持っていることを示す。

\footnotetext{
*大阪電気通信大学

于 572-8530 寝屋川市初町 18-8

Osaka Electro-Communication University

18-8, Hatsu-cho, Neyagawa 572-8530
}

\section{2. ハイブリッド形イミタンス変換器}

入力に巻線比 $a: 1$ のトランスを持つハイブリッド形イミ タンス変換器を図 1 に示す。理想変圧器の場合, 入力 $1-1^{\prime}$ 端子と出力 2-2'端子間の入出力関係は, L, C の共振角周 波数 $\omega_{r}=1 / \sqrt{C L}$ が電源の角周波数 $\omega$ に等しいとき,

$$
\begin{gathered}
{\left[\begin{array}{c}
\dot{V}_{1} \\
\dot{I}_{1}
\end{array}\right]=\left[\begin{array}{cc}
j \frac{a}{2 Q} & j a Z_{0} \\
j \frac{1}{a Z_{0}} & j \frac{1}{2 a Q}
\end{array}\right]\left[\begin{array}{c}
\dot{V}_{2} \\
\dot{I}_{2}
\end{array}\right] \ldots \ldots \ldots \ldots \ldots \ldots} \\
\text { ただし, } Z_{0}=\sqrt{L / C}: \text { 特性インピーダンス } \\
Q: \mathrm{L} \text { の } \mathrm{Q}
\end{gathered}
$$

となる。 $Q$ が大きいとき四端子定数の $A=D=0$ となるの がイミタンス変換器の特徵で, 上式より入出力の関係は次 式のようになる。

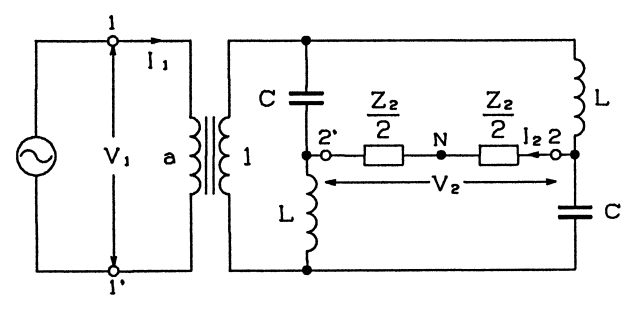

図 1 ハイブリッド形イミタンス変換器

Fig. 1. Hybrid immittance converter with transformer. 


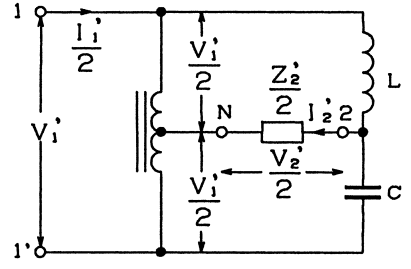

図 2 オートトランスで $\mathrm{N}$ 点を固定

Fig. 2. Voltage of $\mathrm{N}$ is fixed by an auto transformer.

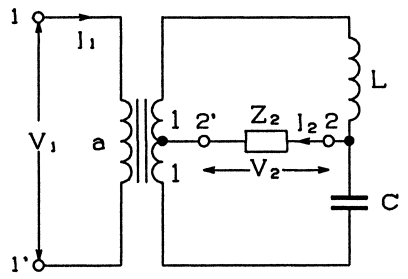

図 3 ハーフブリッジ形イミタンス変換器

Fig. 3. Half-bridge type immittance converter.

$$
\left.\begin{array}{l}
\dot{I}_{2}=-j \frac{1}{a Z_{0}} \dot{V}_{1}-\frac{1}{2 Q Z_{0}} \dot{V}_{2} \approx-j \frac{\dot{V}_{1}}{a Z_{0}} \\
\dot{V}_{2}=-j a Z_{0} \dot{I}_{1}-\frac{Z_{0}}{2 Q} \dot{I}_{2} \approx-j a Z_{0} \dot{I}_{1}
\end{array}\right\}
$$

$Q$ が大きければ出力電流 $I_{2}$ は入力電圧 $V_{1}$ によってきまり, ほとんど $V_{2}$ の影響を受けないので，定電圧源が定電流源 に変換できる。また，定電流源は定電圧源に変換できる。

効率は, $V_{2} / V_{1}$ の関数で表すと次式となる。

$$
\eta=\frac{1}{1+\frac{1}{Q}\left\{1+\frac{1}{2}\left(\sqrt{\frac{V_{1}}{a V_{2}}}-\sqrt{\frac{a V_{2}}{V_{1}}}\right)^{2}\right\}}
$$

効率は， $V_{1} / V_{2}$ がトランスの巻き線比に等しいとき，すな わち負荷インピーダンスが特性インピーダンスに等しいと きに最大となり, 理想変圧器で $Q=100$ ならば $\eta=99 \%$ と なる。

\section{3. ハーフブリッジ形イミタンス変換器}

図 1 で $a=1$ のとき，負荷を $\mathrm{Z}_{2} / 2$ ずつに分けて考える と, その中点 $\mathrm{N}$ に対して回路は対称となっているので, 中 点の電圧は常に $V_{1} / 2$ である。したがって， $\mathrm{N}$ 点の電圧を $V_{1} / 2$ に保つならば，図 2 のように負荷 $Z_{2} / 2$ に対して片方 の LC 回路で同じ電流 $I_{2}$ が供給される。

図 3 のように，トランスの中点タップを $\mathrm{N}$ としたハーフ ブリッジ形イミタンス変換器を提案する。図 1 図 3 の回 路パラメータの関係は次のようになる。

$$
\dot{Z}_{2}=\dot{Z}_{2}^{\prime} / 2, \quad \dot{V}_{1}=\dot{V}_{1}{ }^{\prime}, \quad \dot{V}_{2}=\dot{V}_{2}{ }^{\prime} / 2, \quad \dot{I}_{1}=\dot{I}_{1}{ }^{\prime} / 2, \quad \dot{I}_{2}=\dot{I}_{2}{ }^{\prime}
$$

ただし，図 1 中の $\dot{Z}_{2}, \dot{V}_{1}, \ldots$ 等は $\dot{Z}_{2}{ }^{\prime}, \dot{V}_{1}{ }^{\prime}, \ldots$ 等で表し た。その結果，トランスの巻き数比を $a: 1: 1$ とし，特性 インピーダンスを

$$
Z_{0}=\sqrt{L / C} / 2
$$

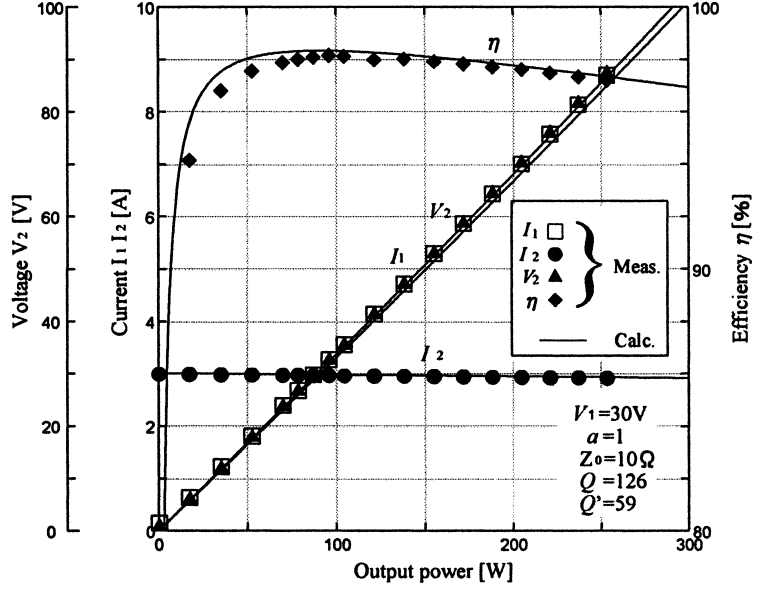

図 4 変換特性 $(f=14.7 \mathrm{kHz})$

Fig. 4. Conversion characteristics $(f=14.7 \mathrm{kHz})$.

とすれば,ハーフブリッジ形イミタンス変換器の特性は (1) (3) 式で表され，ハイブリッド形イミタンス変換器と全く同 じ特性を持っていることになる。

定電圧入力の実験例を図 4 に示す。 $Q^{\prime}=59$ はトランス の直列インピーダンスを含めた $Q^{(5)}$ で, 計算值はこれによ る。定電流出力となるので出力は $V_{2}$ に比例し, $V_{2}$ が $V_{1}$ の 0 3 倍の負荷変化に対して出力電流変動率は $2.56 \%$, 最高 効率は $V_{2}$ が $V_{1}$ にほほ等しい $V_{2}=33 \mathrm{~V}$ のとき $98.2 \%$ と なった。

4. むすび

ハーフブリッジ形イミタンス変換器は，センタタップト ランスと L, Cがそれぞれ一個ずつで実現できるので，共振 周波数の調整が容易である。入出力特性はハイブリッド形 イミタンス変換器と同じで効率が高く, 負荷変動が小さい。

(平成 18 年 2 月 8 日受付)

\section{文献}

(1) H. Seidel: "A High Power Factor Tuned Class D Converter", PESC'88, pp.1038-1042 (1988)

(2) H. Yamana and H. Irie: "Immittance Converter in a Switching Mode Power Converter", National Convention Record of IEE Japan, No.817 (1996) (in Japanese)

山名晴久・入江寿一：「イミタンス変換器を使用した電力変換装置」, 平 8 電学全大, No.817 (1996)

(3) H. Irie and H. Yamana: "Immittance Converter Suitable for Power Electronics”, IEEJ Trans. IA, Vol.117, No.8, pp.962-969 (1997-8); Electrical Engineering in Japan, 124-2, pp.53-62 (1998) (in Japanese)

入江寿一・山名晴久：「パワーエレクトロニクスに適するイミタン 変換器」, 電学論 D, 117, 8, pp.962-969 (1997-8)

4 ) H. Irie and Y. Kawabata: "Hybrid Type Immittance Converter", IEEJ Trans. IA, Vol.121, No.1, pp.119-124 (2001-1); Electrical Engineering in Japan, 138-3, pp.80-86 (2002) (in Japanese)

入江寿一・川端祐一：「ハイブリッド形イミタンス変換器」, 電学論 D, 121, 1, pp.119-124 (2001-1)

(5) N. Takayama and H. Irie: "Half-Brige Type Immittance Converter", Proc. of the 2004 Japan IAS Conference, 1-133, pp.1/581-586 (2004) (in Japanese) 高山長之・入江寿一：「ハーフブリッジ形イミタンス変換器」, 電学 産業応用部門大会, 1-133, pp.1/581-586 (2004) 